$0-421$ 滕田保健衛生大学:

low dose cyclosporine (CsA)を用いた 4 剂 併用免疫療法による死体腎移植 61 例の検討

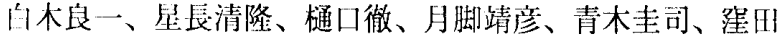

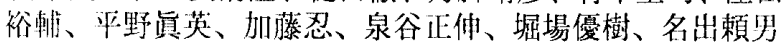

【山的】我が国の心臓死ドナ一を用いた腎移植において、 臓器摘怘時の温阳血並びに移植後無尿期における維持療法 が移植後腎機能に大きな影響を与える。この点より、移植 後高則に充分かつ臓器損賃を来さ無い免疫抑制療法が必罗 と考えられる。そこで、当科では low dose CsAを用いた 4 剂价用免没抑制プロトコールを確立し、その成績を検討し た。【刘象】1990年10月〜96年 8 月に施行した死体腎移植 61 例で、ドナー及びレシピエント年柃は各々 3〜67(平均 45.2)歳、15〜59 (平均 39.0)歳であった。温阻血時間は1 ５2(平均 10.2)分で、low dose CsA (4 mg/kg/day)に加え、 ステロイド、抗リンパ球抗体、アザチオプリン(後にミソ リビンに変更)の 4 剂にて免疫抑制療法を施行した。【絬 果】 $2 \sim 72$ ヶの移植後観察期間にて、61例中54例は平均 $\mathrm{s}$-Cr.值1.8mg/dl で生着している。14例 (23.3\%)は術直後よ り利尿を㢹め、45例(75\%)は 1 ～47(平均 12.7)日のA T N 期 阔を、また1例にprimary non-functionを認めた。2例が移 泚朔よりの合㴊聇が原因で、各々移植後 1,13 ヶ月にて死じ した。5 年生存率は $96.3 \%$ \%す、3 年及び5 年生着率は 齐々94.7、86.5\%であった。移植後 6 ヶ月以内の急性拒絶 反応は13例 $(21.3 \%)$ に認めたが、いずれも治療に反応し た。合作症として、糖疗病14例(長期insulin必要例は2例)、 月下㙨能障害16例、白内障16例(手術9例)、大腿骨頭壊死6例

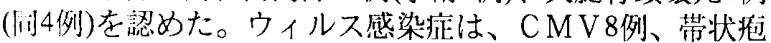
骖8例等を認めたが、重篤なものは無かった。【結論】心 臟北ドナーを井いた死体腎移植において、low dose CsAを 川いた 4 剂仿朋撩法は優れた负疫抑制療法と考えられた。

\section{O-423免疫抑制剤 4 郕併用瘵法を用いた死体腎 移植患者における移植後感染症}

\section{藤田保煡衛生大学}

星長清隆・白木良一・泉谷正伸・月脚靖彦・平野而英

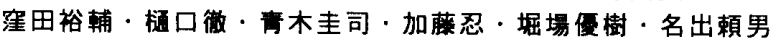

【目的】死体堅移植直後より使用したciclosporin (CsA)、 methylprednisolone (MP) 、azathioprine (AZA)、ALGによ る4 郕併用湶法が移植患者の感染症に影篅を及ほしているか を検討した。【対象と治康法】対象患者は当施設で死体㹂移 植を受け、2ヶ月以上経過を誰察し得た 61 例で、移植時年 齢は平均 39 瓷である。免疫抑制はCsAを術直後より経口典

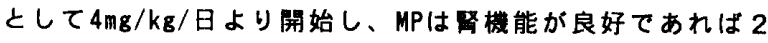
ヶ月後には 1 日投与县を $0.25 \mathrm{mg} / \mathrm{kg} 、 1$ 年後には $8 \mathrm{mg} 、 3$ 年後 には4mgとした。AZAは $1.5 \mathrm{mg} / \mathrm{kg}$ を投与し、㹂機能の回復を待 ってmizoribine 3mg/kgに变更した。ALGは1gを術後14日間投 与した。尿道カテーテルの留置は原則的に術後 5 日間とし、 この期間のみ抗生剂(PIPC $2 \mathrm{~g} \times 2 /$ 日) を使用し、抗面菌都や $\mathrm{S} T$ 合都は用いなかった。【結果】死亡例は 2 例で、死因は 消化管出血と肝硬変であった。患者生存率は移植後 1 年、3 年、5 年でそれぞれ98.3\%，96.2\%，96.2\%て、同時期の㹩生 肁率はそれぞれ96.6\%，94.6\%，89.6\%と良好な結果であった。 感冒や皮用真菌症などを除外した感染症は下表のとおりで、 生命予後に関わる重篇な感染症は認めなかった。

刢部 肺炎前立腺炎膀腅资 / CMV HSV VZV Adeno / HCV

【考察】本プロトコールにより、死体腎移植後の急性拒絶反 応が軽渴し良好な生着率が得られたと同時に、長期的にはス テロイド投与目の隇吾が図れる結果、移植患者の生命予後に 関わる重籊な感染症の出現を防止出来たと考えられた。

\section{O-422 新規免疫抑制剤FTY720による移植腎生着} 延長効果

大阪医科大学 11 . 大阪大学 $21 \cdot$ 国立小児病院、小览医 療センター 31

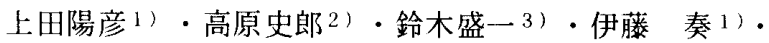
東 治人 1) ・ 岩本勇作 1) ・ 瀬川直樹 1) - 王 昌釬 2) ・

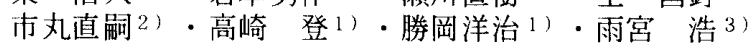

【目的】FYT720は、冬虫夏草菌の一種Isaria sinclairiの 培養濾液から分離されたISP-1から化学修飾によって得 られた免疫抑制剤である。今回、ラット腎移植モデルを 用いて本薬剂が腎移植生着に及ぼす影響を検討した。

【方法】腎移植はWKAH（RTI $\left.{ }^{k}\right)$ をドナ一、Lewis

（RTI'）をレシピエントとした。FTY720を以下の如く、 レシピエントに経口投与した。

1 群：FTY720非投与、 2 群 : $0.1 \mathrm{mg} / \mathrm{kg} /$ 日、術後 14 日間、 3 群: $0.5 \mathrm{mg} / \mathrm{kg}$ /日、術後14日間、 4 群: $1 \mathrm{mg} / \mathrm{kg} /$ 日、 術後14日間、 5 群： $3 \mathrm{mg} / \mathrm{kg} /$ 日、術後14日間、6 群： 3 $\mathrm{mg} / \mathrm{kg} /$ 日、術前 2 日間、 7 群 : $5 \mathrm{mg} / \mathrm{kg} /$ 日、術前 2 日間 【結果】移植腎の生着日数（いずれも $\mathrm{n}=5$ ） は 1 群 : $7.2 \pm 0.4 、 2$ 群 : $11.2 \pm 2.4(\mathrm{p}<0.05) 、 3$ 群 : $13.6 \pm$ $0.9(\mathrm{p}<0.01) 、 4$ 群 : $14.6 \pm 1.7(\mathrm{p}<0.01) 、 5$ 群 : $20.2 \pm 0.8(\mathrm{p}<0.01) 、 6$ 群 : $13.0 \pm 0.7(\mathrm{p}<0.01) 、 7$ 群 : $19.8 \pm 2.1 （ \mathrm{p}<0.01 ）$ であり、FTY720投与によって 有意に延長した。FTY720（3 mg/kg/日、14日）投与群 では、末梢血リンパ球数の有為な減少が認められた。組 織学的にも非投与群と比較して糸球体、尿細管の構築が よく保たれ細胞浸潤は殆ど認められなかった。

【結論】FTY720は、同種腎移植片の有意な生着延長を もたらした。移植前 2 日間投与は、移植後14日間投与と ほぼ同程度の効果が認められた。

\section{O-424 血液型不一致腎移植症例の長期成績について}

東京女子医大泌尿器科 ${ }^{1)}$ 、第 3 外科 ${ }^{22}$

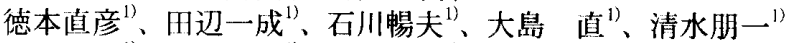
古賀祥嗣 ${ }^{12}$ 、合谷信行 ${ }^{12}$ 、八木沢隆 ${ }^{1)}$ 、中沢速和 ${ }^{1)}$ 、河合達郎 ${ }^{2)}$ 渕之上昌平 ${ }^{2)}$ 、東間 紘 ${ }^{11}$ 、太田和夫 ${ }^{23}$

目的：1983.2月～1995.12月までに東京女子医大腎センター で行った腎移植1080例のうち血液型不一致腎移植症例の 長期成績について検討した。対象 : 腎移植 1080 例のうち 血液型不一致腎移植症例160例を対象にした。結果：160 例中生体腎移植は156例（97.5\%) 死体腎移植症例は4例 であった（2.5\%）。160例中109例は男性、51例は女性で あった。平均年齢は30.8才。平均観察期間は、80.1个月で あった。160例のうち各血型不一致別では、 $\mathrm{O} \rightarrow \mathrm{A}: 56$ 例 $(35 \%) 、 \mathrm{O} \rightarrow \mathrm{B}: 45$ 例 (28.1\%)、O $\rightarrow \mathrm{AB}: 5$ 例 $(0.3 \%)$ 、 $A \rightarrow A B: 33$ 例 $(20.6 \%) 、 B \rightarrow A B: 21$ 例 (13.1\%) であっ た。160例の生存率は、1年、5年、10年でそれぞれ96.9\%、 $90.5 \% 、 85.9 \%$ で、グラフト生着率は、1年、5年、10年で それぞれ $92.4 \% 、 75.3 \% 、 63.0 \%$ あった。各血型不一致 別5年生存率での比較では $\mathrm{O} \rightarrow \mathrm{A} 、 \mathrm{O} \rightarrow \mathrm{B} 、 \mathrm{O} \rightarrow \Lambda \mathrm{B} 、 \mathrm{~A} \rightarrow \mathrm{AB}$ 、 $\mathrm{B} \rightarrow \mathrm{AB}$ でそれぞれ $87.4 \% 、 95.1 \% 、 80 \% 、 93.5 \% 、 85.1 \%$ で、5年生着率ではそれぞれ $72.0 \% 、 72.4 \% 、 60 \% 、 74.2 \%$ 、 $94.7 \%$ でった。結論：血液型不一致腎移植症例の生存率 および生着率は、概ね良好であった。 